Revue Française de Civilisation Britannique

\title{
Independent Labels in the 1980s: Between the Underground and the Mainstream
}

Les Labels indépendants dans les années 1980 : entre marginalité et conformisme Jeremy Tranmer

\section{OpenEdition}

\section{Journals}

Electronic version

URL: https://journals.openedition.org/rfcb/8297

DOI: $10.4000 /$ rfcb.8297

ISSN: 2429-4373

\section{Publisher}

CRECIB - Centre de recherche et d'études en civilisation britannique

Electronic reference

Jeremy Tranmer, "Independent Labels in the 1980s: Between the Underground and the Mainstream", Revue Française de Civilisation Britannique [Online], XXVI-3 | 2021, Online since 14 December 2021, connection on 04 January 2022. URL: http://journals.openedition.org/rfcb/8297 ; DOI: https://doi.org/ $10.4000 / \mathrm{rfcb} .8297$

This text was automatically generated on 4 January 2022.

Revue française de civilisation britannique est mis à disposition selon les termes de la licence Creative Commons Attribution - Pas d'Utilisation Commerciale - Pas de Modification 4.0 International. 


\section{Independent Labels in the 1980s: Between the Underground and the Mainstream}

Les Labels indépendants dans les années 1980 : entre marginalité et conformisme

Jeremy Tranmer

\section{Introduction}

1 In the 1980s, the music industry was very much under the control of the 'majors', that is a small number of powerful companies which signed and promoted the most commercially successful acts. Six multinational companies dominated the music market: BMG (Germany), EMI (United Kingdom), PolyGram/ Philips (Holland), Sony (Japan), Time/Warner (United States) and Universal (United States). These companies and their subsidiaries accounted for over $80 \%$ of the singles and albums sold each year during the decade with artists such as Michael Jackson, Dire Straits and Queen dominating the British charts. The majors can therefore be considered as forming the mainstream of the music industry. The most radical opposition to the mainstream could be found in the anarcho-punk scene which appeared in the late 1970s around the group Crass. Crass was an anarchist band which released its own albums before releasing those of other like-minded bands. This underground scene totally rejected the mainstream music industry for musical and ideological reasons, seeking to exist in opposition to it and outside of it.

2 Seen from this perspective, the mainstream and the underground were the two extremes of a spectrum. Between them were independent labels, some of which were closer to the mainstream, while others were closer to the underground. During the late 1970s and the 1980s, independent labels played a significant role in popular music. Although small labels had always existed on the margins of the music industry, the DIY spirit of punk radically changed their numbers and outlook, and in the late 1970s, labels such as Stiff, Rough Trade, Cherry Red, Mute and Factory were founded. The 
creation of the independent singles and albums charts and the coverage given to them in weekly music papers such as the New Musical Express ${ }^{1}$ and by the DJ John Peel ${ }^{2}$, raised the profile of independent labels, as did the commercial success of 'indie' bands such as the Smiths.

This article will attempt to bring out the specificities of independent labels by examining three fundamental issues concerning them during this period. Firstly, it will study the ideological underpinning of the raison d'être and activities of independent labels, examining the values they espoused and linking them to the general context of the time. Secondly, it will look at how they engaged with the mainstream music industry and also how they attempted to differentiate themselves from it, as well as from more underground activities, such as those of the collective based on Crass. Finally, it will move on to the relationship between the ideological positions of independent labels and the music played by the bands they promoted.

\section{The emergence and consolidation of independent labels}

4 It is tempting to see independent labels emerging with punk or on the back of punk, especially as many independent labels did appear at the same time as punk or just after. However, this vision is partly due to punk's somewhat disingenuous 'year-zero' discourse, which suggests that it entailed a total break with everything that had come previously in the music industry. In fact, the appearance of British independent labels can be traced back to 1939 when Topic Records was founded. ${ }^{3}$ Topic was an offshoot of the Workers Music Association, which was closely aligned to the Communist Party of Great Britain. Topic specialised in left-wing and Soviet music but also released American blues. In the 1950s, it was heavily involved in the folk revival, releasing music by Ewan MacColl and Pete Seeger, for example. In 1949, Polygon Records was created and published the recordings of the singer Petula Clark. Both Topic and, to a lesser extent, Polygon published music that the majors were not interested in since it did not have the potential to be commercially successful and would not provide large profit margins. They also gave their artists a significant degree of influence over what music was released and when it was released. Artists thus had more control over their careers. In the 1950s, Ember Records specialised in jazz, while from the mid to late 1960s the label Immediate concentrated on blues artists such as John Mayall and Fleetwood Mac (although groups such as the Small Faces were also on its roster). Again, artists were given much more autonomy than they would have been granted by a major. The late 1960s and early 1970s saw the appearance of two important independent labels - Island and Virgin. Island specialised in progressive rock before moving on to reggae. Virgin released the extremely successful instrumental album Tubular Bells by Mike Oldfield. However, Virgin's exploitative attitude to its artists was little different to that of the majors.Indeed, Richard Branson, the founder of Virgin, admitted to having little real interest in music ${ }^{4}$, and both labels used the distribution channels of majors.

5 Developments in the 1970s, even excluding the appearance of punk, were conducive to the questioning of the traditional functioning and practices of the music industry. In some circles, the subversive influence of the counterculture of the late 1960s could still be felt, with free festivals still being organised and concerts being held in buildings that 
were occupied by squatters. Marxism was very prominent in intellectual and political debates. For instance, academics questioned traditional conceptions of popular culture in the field of Cultural Studies, while publications of the Communist Party of Great Britain (Marxism Today) and the Socialist Workers Party (Socialist Worker) ran articles about the relationship between popular culture and politics. ${ }^{5}$ Some Marxists, particularly in the Communist Party, were also attempting to integrate into their thinking 'prefigurative' notions that feminists had pioneered. These entailed "making changes now that will prefigure the form of society you would like to live in" rather than waiting for a revolution to build a new society. ${ }^{6}$

6 From 1975 onwards, Rock Against Racism became a dynamic movement putting theory into practice and bringing together activists and lovers of music. ${ }^{7}$ It should also be borne in mind that advances had been recently made in studio technology and the cost of recording a single had fallen. It was in this context that Rough Trade, probably the most famous independent label, was created. ${ }^{8}$ Its founder Geoff Travis had been involved in the counterculture and was sympathetic to the ideas of the radical left. He had also lived on a kibbutz when he was a child. Rough Trade began in 1978 as a record shop stocking independent records before beginning to issue its own singles and albums. From its foundation, Rough Trade functioned as a cooperative with all workers receiving the same wage and as a collective with employees intervening in all aspects of the process of releasing music. It thus deliberately shunned orthodox management and organisation. ${ }^{9}$

7 Punk had a transformative effect on Rough Trade and on the evolution of independent labels in general, leading to the creation of new labels and breathing new life into established ones. Punk was a musical, cultural and social phenomenon which had an impact on music, dance, clothes and ideas. One of its most distinguishing features was the DIY (Do It Yourself) ethos. ${ }^{10}$ DIY was a product of the context in which punk appeared. James Callaghan's Labour government was bogged down in economic difficulties and seemed unable to stop the steady rise of unemployment. As social programmes were slashed, many young people concluded that they could not count on the government to solve their problems and that they had to look after themselves. For example, fanzines encouraged punks to learn how to play a guitar chord, start a band, play concerts and put on concerts for others. DIY, or self-empowerment, encouraged young people to become active and take control of their own lives. This attitude was embodied by the Buzzcocks when they created their own label New Hormones and released themselves their EP Spinal Scratch. ${ }^{11}$ This was a significant development, as it demystified the process of recording a record and it took place in provincial Manchester rather than London, where the music industry was based. It led to other bands creating their own labels and releasing their own singles. The band Scritti Politti took the process of demystification one step further when they printed on the cover of their single 'Skank Bloc Bologna' a breakdown of the costs involved in producing it. ${ }^{12}$ For many bands, production costs were paid for by savings resulting from squatting, unemployment benefits and student grants. Bands also benefited from the boom in the sales of records which took place in 1978.

8 Punk gave some existing or recently-created labels a new lease of life. This was the case of Stiff, whose self-deprecating, provocative style tied in nicely with punk. Stiff released 'New Rose' by the Damned, which is generally considered to be the first punk single. This suggested that the independent labels were capable of reacting more 
quickly than majors to new musical trends. This seemed to be confirmed when in 1979 Rough Trade became the first independent label to have a top twenty record when Stiff Little Fingers' first album reached number 14, selling 115,000 copies. Punk and postpunk also had an ideological impact on Rough Trade, as it signed several feminist bands such as the Raincoats and subsequently refused to release sexist material. However, for its critics, the label had become dogmatic and was favouring political bands. ${ }^{13}$

Despite the changing political and ideological context, the impact of DIY continued after the decline of punk, well into the 1980s as a variety of independent labels were created, including Postcard, Go! Discs, Creation and Sarah Records. Some were run as cooperatives and/or were highly political. Sarah Records, for example, published a fanzine including commentary on the social and political situation in the late 1980s and released the first song which was critical of the Conservative government's new local tax, widely dubbed the Poll Tax ('Defy the Law' by the Orchids).

While others were simply small businesses. Alan McGee, who founded Creation in 1983, made it clear that his only aim was to become rich, to take drugs and to sleep with a lot of women. Moreover, he openly rejected what he termed the "worthy bullshit" of other independent labels. ${ }^{14}$ Creation was in many ways a product of the changing context, the rise of Thatcherism and the spreading of Thatcherite ideas, such as individualism, private enterprise and the importance of the free market. Interestingly, McGee admitted that he had received money from the government via the Enterprise Allowance Scheme to finance the founding of Creation, confirming that he saw the label as nothing more than a small business. ${ }^{15}$

11 However, what many independent labels had in common was that they encouraged original work that was ignored by the majors, responded to new musical trends, believed that commercial success was not necessarily the be all and end all, and experimented with new forms of organisation and production. Or as the author of a history of the Factory label put it, independent labels were "a bubbling mass of ideas and ideology, a hopelessly optimistic and unworkable set of ethics and, most important of all, a good deal of solid enthusiasm." ${ }^{16}$

\section{Relations between independent labels, the mainstream and the underground}

Independent labels were clearly in competition with each other to sign bands which had been overlooked by the majors. This competition was heightened by the appearance of the independent singles and albums charts in January 1980. Previously, singles and albums released by independent labels had struggled to enter the mainstream charts. Only sales from the main retail outlets were included, and many refused to stock independent releases as there was no guarantee that they would sell in large numbers. Sales in small independent record shops were thus not included. Independent labels were often quite ambivalent regarding commercial success. Although, as mentioned above, commercial success was not the sole objective for independent labels, they needed their bands to sell a minimum number of records simply to survive. If a particular record sold well and reached a high spot in the independent charts, it gave the label it was released on more visibility and publicity. 
13 Nevertheless, a positive relationship existed between most independent labels because of their status as outsiders. This encouraged them to share knowledge, for example. In the late 1970s, several labels contacted Stiff to ask how it had manufactured and released the single 'New Rose' by the Damned. ${ }^{17}$ Stiff responded, not by withholding information in order to maintain an advantage over other labels, but by sharing it. It produced a sheet of detailed information which it photocopied and sent to other labels in order to help them. Another example of this cooperation is related to attempts to avoid the majors' distribution networks and to develop alternative networks. ${ }^{18}$ This was of fundamental importance if records were to find their way to shops and to fans and potential buyers (although mail order was still an important means of buying records). A loose conglomerate of associated, regional distributive businesses had existed since 1977, but in 1982 it became formalised and more closely coordinated under the auspices of Rough Trade. Records were sent to regional centres such as Liverpool, York, Norwich, and Edinburgh, and then distributed to independent record shops. The Cartel, as it was known as, was a significant development, allowing small labels to sell their records throughout the country. The outsider status of independent labels also fostered a positive relationship between bands belonging to the same label. Although personal and musical rivalries could exist, there was frequently a sense of friendship and camaraderie between bands, which was rarely the case concerning the majors. The most significant expression of this was joint tours that independent labels such as Stiff and Sarah Records organised for their bands. They involved bands spending a great deal of time together, on buses and in hotels for example, for the duration of the tours.

Although independent labels expressed ideological opposition to the majors and attempted to avoid dealing with them as much as possible, there was, to a certain extent, a relationship of interdependency between them. Independent labels were a source of talent for the majors. Independent labels nurtured new bands, many of which then moved on and signed contracts with majors. Majors were able to offer more lucrative contracts, and equally importantly, they were prepared to spend much more on recording and promotion, if they thought a band had a serious chance of being successful and selling a significant number of records. The fact that independent labels only had limited funds available for recording and promotion was a frequent source of frustration for ambitious bands. Independent labels also sometimes needed the facilities that majors could provide. This is illustrated by the story of 'New Rose' by the Damned. Stiff was unable to press enough copies of the single to meet the high level of demand for it. The majors had their own factories capable of producing large numbers of records in a short space of time. Stiff therefore asked United Artists/EMI to press more copies of 'New Rose'. ${ }^{19}$ In this case, Stiff's ideals were a victim of the label's success. Technically speaking, it ceased to be an independent label, although it could be argued that it simply used EMI's facilities for one particular venture and did not become dependent on the multinational.

The success of Rough Trade in the mid-1980s also led it to question its long-held principles. ${ }^{20}$ The label had grown significantly in the first half of the 1980s, resulting in it employing more people. The new employees had specialised skills but did not necessarily share the overall ethos of the label. Moreover, the increased numbers of employees led to a shift from cooperative structures to more conventional forms of management. This was made official in 1987 when equal pay for all employees was abandoned in favour of a new system based on performance-related pay and profit- 
sharing. The regionalism of the Cartel was replaced by a centralised system. This general trend was strengthened by the Smiths, by far the most successful band on the Rough Trade roster. ${ }^{21}$ Their commercial success was such that it helped Rough Trade to finance many other bands. However, the Smiths were able to use this as a bargaining chip and negotiate more funds for promotional work. In other words, they demanded and received preferential treatment. All of this is not to suggest that Rough Trade simply capitulated to the Thatcherite ideas of individual rather than collective achievement. In some ways, it was a pragmatic response to the situation that the label found itself in. Nevertheless, it was a response which took it away from its origins and corresponded to the dominant ideas of the time. The anti-capitalist ideals that had underpinned the label's general approach since its creation sat uncomfortably with the neo-liberalism advocated by the Thatcher government and its supporters in the rightwing press the press.

The evolution of Rough Trade led the qualitative gap between the label and the majors to be reduced as it shifted along the spectrum in their direction. The anarcho-punk scene remained in total opposition to the mainstream, even if this entailed limiting its potential impact. In the words of one historian of this scene, the appearance and approach of Crass was a fundamental turning point: "No more corporate companies misrepresenting our music; this was the birth of genuinely DIY labels, whose records were sold at virtually cost price, and bearing 'Pay No More Than...' notices to make sure they were." 22 Crass set up their own eponymous label and used profits to release records by other bands, such as the Poison Girls. The latter were encouraged to use their experience of working with Crass to start their own labels. However, when it became clear that some artists were not capable of doing this, Crass created Corpus Christi as a secondary label for other bands. Although the two labels created by Crass were clearly independent, they were markedly different to most other independent labels.

17 Nevertheless, both the anarcho-punk and some independent labels were openly critical of the Thatcher government. In 1982, Rough Trade expressed its collective support for striking nurses, closing its office and joining a demonstration by nurses. The same year, it also openly opposed the Falklands War and released Robert Wyatt's version of the Elvis Costello song 'Shipbuilding'. Rough Trade also supported the miners during the strike of 1984/85, releasing the benefit single 'Strike!' by the aptly-named Enemy Within and donating records to the children of striking miners. Rough Trade's opposition to Thatcher was rooted in the ideals that had led to its creation. However, this led to tensions with some of the bands on Rough Trade. For Johnny Marr of the Smiths, this was dogma which belonged to another period of history. He shared Rough Trade's hostility to Thatcher but favoured a more pragmatic, contemporary form of opposition that was less grounded in utopian principles. ${ }^{23}$

Crass and various anarcho-punk bands and labels undertook a wide variety of activities against Thatcher and expressed opposition to capitalism in general. The members of Crass lived on a commune and sought to promote an alternative lifestyle based on pacifism and vegetarianism. They were highly active in the Campaign for Nuclear Disarmament and in the Stop the City demonstrations of the early 1980s. Their attitude to the music industry and the coherence between their lifestyle and their politics were an inspiration to budding musicians, including future members of the band Chumbawamba. ${ }^{24}$ Unsurprisingly, the majors did not express hostility to the Thatcher 
governments, although some of their artists were involved in various oppositional movements. Most notable among these was Paul Weller, whose band the Style Council was on Polydor, a subsidiary of Universal. The band released several songs which openly criticised the Conservatives, played benefits for striking miners and were an essential part of Red Wedge, a movement composed of musicians who supported the Labour Party in the run-up to the 1987 general election.

\section{Independent labels and music} has been the source of some confusion over the years. Independent labels released very varied music, but they were associated with a particular style of music which was called 'indie'. In her study of the genre, Wendy Fonarow noted that it had several distinctive characteristics including its simplicity, a strong aversion to technological innovation, a nostalgic sensibility and the fetishisation of the guitar. ${ }^{25}$ Musically, "indie continues the punk legacy of simplicity, directness, and avoidance of extravagance in musical forms" with three-minute songs and an avoidance of guitar solos. ${ }^{26}$ The guitar sound was often heavily influenced by the American band the Byrds and the jangly guitar sound that they had pioneered in the mid-1960s. ${ }^{27}$ Indie was thus very different from the electropop of A-ha and the Thompson Twins and the smooth, sophisticated soul which dominated the charts in the mid-1980s. Guitars were seen as representing authenticity and emotions in comparison to synthesisers which were viewed as soulless machines.

The most commercially successful examples of indie music include the Smiths ${ }^{28}$ and the Housemartins. ${ }^{29}$ The latter were on Go! Discs, which also had the singer-songwriter Billy Bragg on its roster. The Smiths were without doubt the most visible, controversial and emblematic indie band of the time. ${ }^{30}$ Their career lasted from 1983 to 1987, including four studio albums, three compilation albums, and nineteen singles. Not only did their releases top the independent charts, they also figured in the mainstream charts. Eight of their singles reached the top twenty, and all of their albums reached the top five. No other independent artists achieved such sustained commercial success. At the heart of their music was the combination of the singer Morrissey's unusual vocals and the guitar-playing of Johnny Marr. The four members of the band were born in Manchester and made frequent references to the city in their songs. In interviews with the press they criticised the monarchy (their third studio album was entitled 'The Queen is Dead') and Morrissey advocated vegetarianism (the title of their second album was 'Meat is Murder'). The band attracted a cult following, taking it from the margins of the independent scene to the mainstream of British popular music. The highpoint of indie occurred in 1986 when the weekly music newspaper New Musical Express distributed a free cassette compilation entitled $\mathrm{C} 86{ }^{31}$ It featured 22 tracks by bands who had signed with small independent labels still wedded to the DIY ethos, and all the tracks had the same jangly guitar style, such as the opening track of Primal Scream's 'Velocity Girl'.

21 Some of the above-mentioned artists were overtly political. The Housemartins were actively involved in the miners' strike, playing benefit concerts and attending picket lines. Their first album (London 0 Hull 4) contains several songs such as 'Get up off our knees' and 'Sitting on a fence' which encouraged people to take action against the government. Billy Bragg was extremely active in the miners' strike and helped to create 
the Red Wedge collective which aimed at mobilising musicians in support of the Labour Party in the second half of the 1980s. The Smiths made comments critical of Thatcher in the press and took part in benefits for Red Wedge and for the local council in Liverpool which was under attack from the government. However, most of the indie bands on the C86 collection did not express political opinions, some of them believing that being on an independent label was a political and ideological statement in itself.

The relationship between the ideological and political positions of labels and the music played by the bands they promoted was quite complex. The radicalness of the ideology of anarcho-punk was inextricably linked to the radical nature of the music and the lyrics of the songs. Regarding indie, with exception of the Housemartins, the Smiths and a few others, lyrics were rarely overtly political in any way. The guitar sound was not revolutionary as such, but it clearly went against the dominant trends of popular music at the time, in other words against the music that was produced by the majors and dominated the charts. It therefore signaled a certain form of resistance to the mainstream.

\section{Conclusion}

During the period from 1979 to 1990, record labels could be divided into three categories: the mainstream majors, the underground anarcho-punk labels and independent labels. These three categories were not homogeneous since there were significant differences in approach within each of them. Furthermore, they were neither fixed nor stable as changes took place within and between them. Bands moved from one category to another, frequently from independent labels to majors. On the music industry spectrum, independent labels could be placed between the underground and the mainstream. During the 1980s, significant changes took place involving independent labels. The fortunes of some labels changed dramatically. By the end of the decade, the more distinctive labels were in decline, such as those linked to C 86 as well as Rough Trade. The rise and fall of the latter had a certain symbolic value, seeming to suggest that the alternative model of independent labels had failed. This appeared to be confirmed by the fact that Rough Trade went into administration in 1991. Other labels were more successful, benefiting from the changing musical climate. Factory was closely linked to the 'Madchester' scene around groups such as the Happy Mondays, while Creation was associated with house music and its derivatives. In overall terms, there was a shift by independent labels towards the mainstream. The differences between independent labels and the mainstream were no longer qualitative (most independent labels became orthodox capitalist companies) but quantitative (they were smaller than the majors). This shift was facilitated by the fact that the underground in its Crass-inspired incarnation was in decline by the late 1980s and was no longer an alternative pole of attraction. The blurring of the difference between independent labels and the mainstream is best symbolised by the commercial success of Oasis's 1994 album (What's the Story) Morning Glory?, which was released by Creation. 


\section{BIBLIOGRAPHY}

Benton, Sarah, 'Eurocommunism and The British Road to Socialism' in David Coates and Gordon Johnston (eds), Socialist Strategies, Oxford, Martin Robertson \& Company, 1983, pp. 116-147.

Berger, George, The Story of Crass (Sunderland, PM Press, 2009).

Campbell, Sean and Coulter, Colin (eds), Why pamper life's complexities? Essays on the Smiths (Manchester, MUP, 2010).

Collins, Andrew, Billy Bragg. The Official Biography. Still suitable for miners (London, Virgin Books, 1998).

Coates, David and Johnston, Gordon (eds), Socialist Strategies, Oxford, Martin Robertson \& Company, 1983.

Dale, Pete, Popular Music and the Politics of Novelty (London, Bloomsbury, 2016).

Fonarow, Wendy, Empire of Dirt. The Aesthetics and Rituals of British Indie Music (Middletown, Connecticut, Wesleyan University Press, 2006).

Fountain, Nigel, 'Sex Pistols: Whose finger on the trigger?', Socialist Worker, 18 December 1976, 11. Glasper, Ian, The Day The Country Died: A History of Anarcho Punk 1980-1984 (London, Cherry Red, 2006).

King, Richard, How soon is now? The Madmen and Mavericks who made Independent Music 1975-2005 (London, Faber and Faber, 2012).

Heatley, Michael, John Peel. A Life in Music (London: Michael O’Mara Books, 2005 [2004]),

Laing, Dave, 'Interpreting Punk Rock', Marxism Today, April 1978, 123-128.

Long, Pat, The History of the NME (London, Portico, 2012).

Marr, Johhny, Set The Boy Free. The Autobiography (London, Arrow Books, 2017).

McGee, Alan, Creation Stories. Riots, Raves and Running a Label (London, Pan Books, 2014 [2013].

Middles, Mick, Factory. The Story of the Record Label (London, Virgin Books, 2009 [1996].

Ogg, Alex, Independence Days. The Story of UK Independent Record Labels (London, Cherry Red Books, 2009).

Parkes, Simon and Rafaeli, JS, Live at the Brixton Academy. A Riotous Life in the Music Business (London, Serpent's Tail, 2014).

Renton, David, Never Again. Rock Against Racism and the Anti-Nazi League 1976-1982 (Abingdon: Routledge, 2019).

Reynolds, Simon, Rip it up and start again. Postpunk 1978-1984 (London, Faber and Faber Limited, 2006 [2005])

Swift, Nick, The Housemartins. "Now that's what I call quite good". The Authorised Biography (Hull, Tales From Humberside, 1988).

Taylor, Neil, An Intimate History of Rough Trade (London, Orion, 2012 [2010]).

Whalley, Boff, Footnote* (Hebden Bridge, Pomona, 2003). 
Worley, Matthew, No Future. Punk, Politics and British Youth Culture, 1976-1984, Cambridge, CUP, 2017.

\section{Discography}

Buzzcocks, Spiral Scratch, New Hormones, 1977.

Clark, Petula, "The Little Shoemaker", Polygon, 1954.

Crass, Stations of the Crass, Crass Records, 1979.

The Damned, "New Rose", Stiff Records, 1976.

Enemy Within, "Strike!", Rough Trade, 1984.

Fleetwood Mac, "Man of the World", Immediate Records, 1969.

Happy Mondays, Pills ' $n$ ' Thrills and Bellyaches, Factory, 1990.

Housemartins, London 0 Hull 4, Go! Discs, 1986.

MacColl, Ewan, Shuttle and Cage, Topic Records, 1957.

Mayall, John, "I'm Your Witchdoctor", Immediate Record, 1965.

Oasis, (What's the Story) Morning Glory, Creation, 1994.

Oldfield, Mike, Tubular Bells, Virgin Records, 1973.

Poison Girls, Chappaquiddick Bridge, Crass Records, 1980.

Scritti Politti, "Skank Bloc Bologna", St Pancras Record, 1978.

Seeger, Pete, Pete Seeger's Five String Banjo, Tutor Records, 1959.

The Smiths, The Smiths, Rough Trade, 1984.

The Smiths, Meat is Murder, Rough Trade, 1985.

The Smiths, The Queen is Dead, Rough Trade, 1986.

The Smiths, Strangeways, Here We Come, Rough Trade, 1987.

The Smiths, Rank, Rough Trade, 1988.

Stiff Little Fingers, Inflammable Material, Rough Trade, 1979.

Various, C86, New Musical Express, 1986.

Wyatt, Robert, "Shipbuilding", Rough Trade, 1982.

\section{NOTES}

1. Although its circulation was falling in the early 1980s, the New Musical Express contributed to shaping the tastes of tens of thousands of young British people, and articles about bands on independent labels thrust them into the limelight. Pat Long, The History of the NME (London, Portico Books, 2012), pp. 128-182.

2. During the late 1970 s and 1980s, Peel had a late-night slot on BBC Radio 1 and gained a reputation for playing original and innovative music that was ignored by other DJs as it was not considered to appeal to a mass daytime audience. He was, for example, the only Radio 1 DJ to play 
punk and post-punk records regularly. Michael Heatley, John Peel. A Life in Music (London, Michael O’Mara Books, 2005 [2004]), pp. 104-148.

3. For an overall history of British independent labels, see Alex Ogg, Independence Days. The Story of UK Independent Record Labels (London, Cherry Red Books, 2009). The period until punk is covered from page 5 to 71 .

4. Richard King, How soon is now? The Madmen and Mavericks who made Independent Music 1975-2005 (London, Faber and Faber, 2012), p. xviii.

5. See for example, Nigel Fountain, 'Sex Pistols: Whose finger on the trigger?', Socialist Worker, 18 December 1976, p. 11 and Dave Laing, 'Interpreting Punk Rock', Marxism Today, April 1978, pp. 123-128.

6. Sarah Benton, 'Eurocommunism and The British Road to Socialism' in David Coates and Gordon Johnston (eds), Socialist Strategies, Oxford, Martin Robertson \& Company, 1983, p. 143.

7. David Renton, Never Again. Rock Against Racism and the Anti-Nazi League 1976-1982 (Abingdon, Routledge, 2019).

8. Neil Taylor, An Intimate History of Rough Trade (London, Orion, 2012 [2010]).

9. As a consequence, records were physically present at the offices of Rough Trade. This was not the case of the majors, for which the various stages of the creation and promotion of records were clearly separate. The absence of records in the offices of the majors contributed to the decision of the Smiths, who were to become one of the most important bands of the independent scene in the 1980s, to sign for Rough Trade. Johnny Marr, Set The Boy Free. The Autobiography (London, Arrow Books, 2017), p. 173.

10. Pete Dale, Popular Music and the Politics of Novelty (London, Bloomsbury, 2016), p. 64.

11. Mick Middles, Factory. The Story of the Record Label (London, Virgin Books, 2009 [1996]), pp. 70-72. For some, the creation of new labels outside the mainstream of the music industry was a fundamental tenet of punk. Consequently, when the Clash signed for CBS in 1977, it was seen by Mark Perry, the creator of the influential fanzine Sniffin' Glue, as the end of punk. Matthew Worley, No Future. Punk, Politics and British Youth Culture, 1976-1984, Cambridge, CUP, 2017, pp. 64-66.

12. Simon Reynolds, Rip it up and start again. Postpunk 1978-1984 (London, Faber and Faber Limited, 2006 [2005]), p. 204.

13. Neil Taylor, An Intimate History of Rough Trade (London, Orion, 2012 [2010]), p. 102.

14. Richard King, How soon is now? The Madmen and Mavericks who made Independent Music 1975-2005 (London, Faber and Faber, 2012), p. 219.

15. Alan McGee, Creation Stories. Riots, Raves and Running a Label (London, Pan Books, 2014 [2013]. The Enterprise Allowance Scheme was created by Margaret Thatcher's government to assist unemployed people who wished to create their own company and guaranteed them a fixed income of $£ 40$ per week. Originally a pilot scheme, it was launched throughout the United Kingdom in 1983.

16. Mick Middles, Factory. The Story of the Record Label (London, Virgin Books, 2009 [1996]), p. 151.

17. Alex Ogg, Independence Days. The Story of UK Independent Record Labels (London, Cherry Red Books, 2009), p. 97.

18. Neil Taylor, An Intimate History of Rough Trade (London, Orion, 2012 [2010]), pp. 172-173.

19. Alex Ogg, Independence Days. The Story of UK Independent Record Labels (London, Cherry Red Books, 2009), p. 96.

20. Neil Taylor, An Intimate History of Rough Trade (London, Orion, 2012 [2010], p. 257.

21. Richard King, How soon is now? The Madmen and Mavericks who made Independent Music 1975-2005 (London, Faber and Faber, 2012), p. 276.

22. Ian Glasper, The Day The Country Died: A History of Anarcho Punk 1980-1984 (London, Cherry Red, 2006), p. 8. 
23. Richard King, How soon is now? The Madmen and Mavericks who made Independent Music 1975-2005 (London, Faber and Faber, 2012), p. 168.

24. Boff Whalley, Footnote* (Hebden Bridge, Pomona, 2003), pp. 102-106. However, Crass had their detractors in the music press, who criticised their politics as being simplistic. George Berger, The Story of Crass (Sunderland, PM Press, 2009), pp. 124-125. Furthermore, it has also been suggested that Crass's approach to their music was far from perfect and still left it enmeshed in the capitalist system: "putting petrol in the van, buying food, selling records and so forth are a necessary link from the idealistic punk underground back to the capitalist economic situation which it would oppose." Pete Dale, Popular Music and the Politics of Novelty (London, Bloomsbury, 2016), p. 165.

25. Wendy Fonarow, Empire of Dirt. The Aesthetics and Rituals of British Indie Music (Middletown, Connecticut, Wesleyan University Press, 2006), p. 39.

26. Ibid., p. 42.

27. An obvious example of this is their 1965 cover version of Bob Dylan's 'Mr Tambourine Man' https://www.youtube.com/watch?v=gYLKlgalHMs consulted 28 March 2020.

28. See for example their first single 'This Charming Man: https://www.youtube.com/watch? $\mathrm{v}=\mathrm{cJRP3LRcUFg}$ consulted 28 March 2020.

29. One instance is their first hit 'Happy Hour': https://www.youtube.com/watch? v=7_TMUJIWwyI consulted 28 March 2020.

30. In recent years, the Smiths have received a certain amount of attention from academics. See for example, Sean Campbell and Colin Coulter (eds), Why pamper life's complexities? Essays on the Smiths (Manchester, MUP, 2010).

31. The complete album can be found here: https://www.youtube.com/watch?v=HuGR-8HtyB0 consulted 28 March 2020.

\section{ABSTRACTS}

Although small labels had always existed on the margins of the music industry, the DIY spirit of punk radically changed their numbers and outlook, and in the late 1970s labels such as Stiff, Rough Trade, Cherry Red and Mute were created. In the early 1980s, the creation of independent singles and albums charts (in opposition to the mainstream charts) and the coverage given to them in weekly music papers such as the New Musical Express and Sounds, raised the profile of independent labels, as did the commercial success of 'indie' bands such as the Smiths. This article examines three fundamental issues concerning independent labels during this period. Firstly, it will study the ideological underpinning of the raison d'etre and activities of independent labels and the values they espoused. Secondly, it looks at how they engaged with the mainstream music industry and also how they attempted to differentiate themselves from it, as well as from more underground activities, such as those of the collective based on the punk group Crass. Finally, it moves on to the relationship between the ideological positions of independent labels and the music played by the bands they promoted.

Même si les petits labels ont toujours existé à la périphérie de l'industrie musicale, l'esprit DIY du punk changea radicalement leur nombre et leurs perspectives si bien qu'à la fin des années 1970 des labels tels que Stiff, Rough Trade, Cherry Red et Mute furent créés. Au début des années 1980, la création de classements de singles et d'albums indépendants (par opposition au hit-parade 
classique), leur couverture médiatique dans des hebdomadaires musicaux tels que le New Musical Express ou Sounds, ainsi que le succès commercial de groupes "indie» tels que les Smiths, permirent à ces labels de sortir de l'ombre. Cet article examine trois points fondamentaux relatifs à ces labels indépendants pendant cette période. En premier lieu, il étudie l'idéologie qui soustend la raison d'être de ces labels et de leurs activités, ainsi que les valeurs qu'ils embrassèrent. En second lieu, il analyse les rapports que ces labels entretenaient avec l'industrie musicale «mainstream » et également la manière par laquelle ils tentèrent de se différencier de cette industrie et d'autres activités plus « underground » telles que celles du collectif autour du groupe punk Crass. Enfin, il aborde la relation entre les points de vue idéologiques des labels indépendants et la musique des groupes dont ils firent la promotion.

\section{AUTHOR}

\section{JEREMY TRANMER}

Université de Lorraine

Jeremy Tranmer is a senior lecturer at the Université de Lorraine, where he teaches classes about contemporary British history, politics and popular culture. He completed a PhD about the Communist Party of Great Britain and its opposition to the Thatcher governments and has written widely on the history of the radical left. He is also interested in the relationship between the left and popular music and has published work on Rock Against Racism, the activities of musicians during the miners' strike of $1984 / 85$, and on Red Wedge.

Jeremy Tranmer est maître de conferences à l'Université de Lorraine, où il enseigne la civilisation britannique. Il a soutenu une thèse consacré au Parti Communiste de Grande-Bretagne et à son role au sein de l'opposition aux gouvernements Thatcher. Il a publié de nombreux articles sur l'histoire de la gauche radicale. Il s'intéresse également à la relation entre la gauche et la musique populaire et il a publié des articles sur Rock Against Racism, la mobilisation des musiciens en faveur de la grève des mineurs de 1984/85 et Red Wedge. 